Originalni naučni rad УДК 821.111(73).09-31 Сиснерос С.

$316.7(73)$

Primljen: 31. marta 2021.

Prihvaćen: 24. aprila 2021.

Mirna M. Ćurić ${ }^{1}$

https://doi.org/10.46630/phm.13.2021.23

University of Novi Sad

Faculty of Philosophy ${ }^{2}$

\title{
REFLECTIONS ON POPULAR CULTURE IN SANDRA CISNEROS'S THE HOUSE ON MANGO STREET
}

\begin{abstract}
This paper explores elements of popular culture in Sandra Cisneros' novel The House on Mango Street. The theoretical approach in the first section of the paper introduces the most relevant aspects of early U.S. popular culture, while the second section discusses U.S. popular culture with respect to ethnic minorities, predominantly Chicanas portrayed in Cisneros's novel. The paper highlights certain ambiguities of popular culture in relation to minorities in the U.S., as well as the fact that, though having embraced egalitarian ideals and having general progressive views, popular culture nevertheless has failed to integrate specific cultural and gender perspectives of Latinas, as demonstrated by the lack of representation and stereotyping of female characters in the novel.
\end{abstract}

Keywords: popular culture, media, representation, ethnic minority, Chicanas, gender, patriarchy, Cisneros

\section{Introduction}

The novel The House on Mango Street by Sandra Cisneros was published in 1984 and has since earned critical acclaim in the field of ethnic and transnational literature. Set in a 1950s Hispanic neighborhood known as barrio, Cisneros's novel shows Esperanza Cordero, a young Chicana girl, growing up and inspired by a desire to move to a more affluent area of Chicago. Esperanza recounts numerous happenings from her early life and adolescence in a series of short stories called vignettes, acquainting readers with the way popular American culture interacts with the reality, life, and Latino/a culture of immigrants. In focusing on Esperanza's immigrant experience and life, as well as that of other characters, this paper demonstrates that elements of popular culture have significantly different meanings for ethnic minorities. To understand how and why Esperanza, her parents, and her friends integrate these elements into their own lives, the first section of this paper offers a general description of popular culture, its evolution, and meaning, while the second section focuses 1 mirnabijedicdc@gmail.com

2 The paper was written as part of a doctoral course Popular Culture at the Faculty of Philosophy, University of Novi Sad. 
on fictional examples of popular culture and reproduction of cultural meaning. Unlike her parents, who as first-generation Latino immigrants struggled to integrate into American society and community, Esperanza reacts better to the bicultural background of her everyday life, negotiating cultural opposition and integrating various cultural elements. However, given that early popular culture seldom had any relevant significance for minority groups, and consequently, these groups lacked adequate cultural representation in the U.S., characters like Esperanza were forced to infer their own derived meanings from existing cultural elements. Accordingly, the paper illustrates how aspects of popular culture, such as the trope of the American dream, carnivals, lottery games, and popular products, take on a different importance for the characters like Esperanza. Given that Cisneros is regarded as a Chicana feminist writer, and all her novels deal with the Chicana experience, the final section of the paper explores the manner in which aspects of popular culture favor patriarchal activity against women, highlighting the complex position of the Chicana, due to the fact that these women also face patriarchal oppression in their original Latino culture.

\section{Early Popular Culture: Theoretical Argumentation}

While cultural theorists have a skeptical view for possibly developing a universal definition of popular culture, some have attempted to clarify its origins and meaning. Evaluating the most important aspects of popular culture requires first comprehending the underlying meaning of culture. In the book Keywords: A Vocabulary of Culture and Society, Raymond Williams (1985: 87-88) explains that the term is attributed a semantic ambiguity due to its historical etymology and presents denotations in several scientific disciplines. As Williams explains, in its early stages, the noun referred to production processes and was derived from the Latin colere which originally meant inhabit, cultivate, protect, honor with worship. However, the most prevalent meaning had to do with production and tending. According to Williams, the current word culture in English originated from French, most likely at the turn of the 14th century, or early 15th century, and primarily referred to animal husbandry. However, it was not until the late 18 th and early 19th centuries that the word had taken on meanings other than tending and began to denote civilization and human development (WILLIAMS 1985: 90). From then on, the term gained other meanings, including recent connotations such as lifestyle, living habits, artistic expression, and the like. Contemporary definitions of culture tend to centralize knowledge, technology, values, beliefs, customs, and behaviors common to human beings. However, various cultural theorists stress that culture is neither linear nor singular because human existence reflects a plurality of cultures. Therefore, as Williams notes, it is necessary "to speak of 
'cultures' in the plural: the specific and variable cultures of different nations and periods, but also the specific and variable cultures of social and economic groups within a nation" (2005: 89). Given that cultures have a temporal dimension, we can also speak of a medieval culture, renaissance culture, modern culture, postmodern culture, each attributed temporal and spatial specificity.

In supporting the view that popular culture emerged as an alternative to high culture, John Fiske argues that popular culture was formed "in reaction to dominant powers" and "under conditions of subordination" (1989: 43-46). According to Fiske, popular culture is a system of concepts, attitudes, habits, and viewpoints commonly held by people who do not necessarily share the same social background. Given that popular culture is shared by people from various social classes, the upper class is also able to incorporate some of its elements. As an example, Fiske says that an upper-class businessman may, after finishing his work, take off his suit and go to a football game in casual attire (1989: 43). This is how members of other social strata become involved in popular activities and, at the same time, are linked to lower social classes. Though Fiske argues that popular culture is commonly shared by various classes, Stuart Hall contends that popular culture primarily refers to the marginalized: "The culture of the oppressed, the excluded classes: this is the area to which the word 'popular' refers to us" (1998: 452). Furthermore, many theorists view popular culture rather negatively - as a tool of enslavement employed by Western capitalist society, in which popular culture is industrialized, commoditized, and fetishized for specific purposes of domination. As Bain-Selbo writes, "those in power use the culture industry as a way of controlling or pacifying the general population [...] The products of the culture industry do not spur the imagination or creativity of consumers, and they certainly do not elicit any reflective or critical thought" (2010:2). Fiske, on the other hand, rejects the negative criticism, claiming that, considering its connection with mass production and global commerce, popular culture is an active process of production and transfer of meaning, since it is a culture in which meanings are constantly produced and reproduced (1989: 23). Consequently, there are always elements of popular culture that remain outside the control of those in power, as "the dominant cannot control totally the meanings that people may construct" (FISKE 1989: 45). According to this point of view, popular culture cannot be fully used as a manipulative asset by dominant power blocks, since it is the people who create meanings from its elements.

Comprehending the proliferation of popular culture in the United States requires revisiting political and historical events of the second half of the twentieth century. In 1953, Henry Truman's presidency came to an end, and he was succeeded by Dwight Eisenhower. During Eisenhower's presidency, the United States fought in the Korean War, waged a Cold War against the 
Soviet Union, developed nuclear weapons, and initiated the Space Race. In this period, Americans created a new sense of power resulting from the rapid advancement of science, technology, the economy, as well as political and military interventions. In addition to turbulent historical conditions, including various social and technological developments, new viewpoints on American identity emerged. Following World War II, social dynamics in the U.S. gave rise to a new sense of Americanism, and popular culture became central to the development of national identity. The reason for this lies in the fact that popular culture became easily accessible to people from diverse social backgrounds. As the technology progressed, they were able to easily absorb the culture. Meanwhile, ethnic minorities in the U.S., were still unable to culturally identify with the new-born nation, due to the strong influence of their original cultures and the initial lack of representation of ethnic minorities in American popular culture. As America struggled to promote the developing single monolithic identity, the ambitious effort to provide new points of reference to people across the United States failed. The reason for this was that American society has always been too heterogeneous, incorporating numerous ethnic groups harboring two sources of identification - the American culture and their original culture. In the early second half of the twentieth century, America was still a racially prejudiced environment in which positive images of ethnic minorities were scarce. Therefore, in search of elements to identify with, minorities often turned to their original cultures. As Tim Edensor wrote, the 'wild,' 'vernacular,' 'traditional' and 'regional' cultural elements, ignored or reviled by the national cultural elite, have returned as repressed knowledge and have been reconstructed as part of alternative kinds of national identity (2002: 4). Nonetheless, it was still difficult to avoid the influence of popular culture, and as a result, ethnic minorities, especially second- and third-generation immigrants, found themselves between their original cultures and American popular culture. As noted by Homi Bhabha, in an interview with Jonathan Rutherford, these groups found themselves in a culturally transgressive space that allowed for the juxtaposition of elements from various cultures as well as the negotiation of cultural meanings and images, resulting in cultural hybridity. (RUTHERFORD 1990: 211). The cultural hybridization was also propelled by the inherent dynamics of the popular culture, such as globalization and technological innovation. Advances in telecommunications and modern transportation meant that ethnic minorities were able to easily maintain spatially remote relationships and continue to engage in the lives of distant and remote cultural environments (MUJČINOVIĆ 2004: 65). As a result, easy access to the original culture, aided by developments in American popular culture, was one of the reasons inhibiting full integration of ethnic minorities into American culture and society, and the reason these communities established a 
distinct way of life on the cultural frontier.

Although popular culture generally allowed people to use its components to create subjective meaning, there is no doubt that the U.S. society, patriarchal in nature, has used popular culture to manipulate gender dynamics as well. In the 1950s and 1960s, the entire U.S. cultural system communicated messages of female inferiority, submissiveness, and other forms of misogyny. Female representations conveyed through various popular forms, such as magazines, advertisements, books, and films, were closely linked to domestic female activities. However, the reality was that by the 1950s and 1960s, as a result of World War II, women were no longer limited to homes and had already achieved some degree of independence. With many men deployed to war, women took on traditional male roles and entered the male-dominated arena - the job market - to form a new workforce. However, at the end of World War II, upon the return of men from battlefields, there was once again a need to restore the previous social order, and to return women to their former roles as wives, mothers and housewives in the private sphere. According to Jennifer Holt, popular culture was one of the means used to restore subordinate female positions: "At the close of the war, employers re-established the pre-war sexual division of labor. To justify the discriminatory practices against women, popular culture began to create the concept of the proper role for women" (HOLT 2005: par. 5). Furthermore, Holt contended that popular culture reinforced conventional concepts of femininity, primarily through the media, which promoted a variety of female representations associated with maternity, domesticity, female godliness, sensitivity, and submissiveness: "Studies of postwar culture found that government propaganda, popular magazines, and films reinforced traditional concepts of femininity and instructed women to subordinate their interests to those of returning male veterans" (2005: par. 5). As a result, patriarchal female stereotypes resurfaced again with the development of early popular culture. Some prominent stereotypes were contained in the images of good mother and wife that constructed the housewife stereotype, which held that a woman's position was at home with her family, while others focused on female physical appearance.

The unfair treatment of women was embedded in the U.S. government policy that promoted a stable American family, with a nice home, a working husband, a healthy and obedient wife, and successful and happy children. In constructing some of the popular culture, this family image became a new reality in America's rapidly growing population. According to Bridget O'Keefe, the development of this family model was significant because the government at the time believed that establishing optimistic representations of America was critical for two reasons: (1) to build a sense of security among American citizens and families - especially important during the Cold War years, and 
(2) to create an image of national prosperity (2014: 56). Furthermore, O'Keefe recalls that all women, regardless of race, class, or ethnicity, found themselves in similar subordinate positions given that official policy was committed to building a single American nationality and identity, as well as an image of America devoid of poverty and social problems. Since television and other popular media were often used to present what O'Keefe calls "the best aspects of America" (2014: 56), minorities generally lacked appropriate representations in U.S. popular culture. Moreover, the position of ethnic minority women, like that of the Chicana, was far more complicated than, for example, the position of white women, because Chicana women faced a two-fold marginalization based on gender and ethnicity (MADSEN 2003: 65). Aside from the negative influence of mother and wife stereotypes, ethnic minority women were subject to stereotypes in other ways, including portraying them as poor housemaids and housewives, or even regarding them as highly exotic and sexualized women, further reducing them to sexual objects. Consequently, the role of ethnic minority women in the 1950s and 1960s became more challenging, since these women were forced to conform to patriarchal standards embedded in both U.S. popular culture and their original culture, while confronting prejudice and practices of ethnic and social discrimination in the United States.

\section{Elements of Popular Culture and Reproduction of Meaning in The House on Mango Street}

Cisneros's novel The House on Mango Street, set in America in the 1950s, contains elements of popular culture in sharp contrast with those of Latino/a culture and tradition. The American setting in the novel is generated by the repeated invocation of popular images, famous people, and objects of the period - all of which can be identified as symbolic elements of 1950s popular culture. Examples such as TV, radio, the Beatles, Merlyn Monroe, Marlon Brando, and Bugs Bunny are found in many vignettes, suggesting that the 1950s was the time when popular culture began its broad spread throughout American society, touching every social stratum, including U.S. immigrant communities. This supports Fiske's theoretical argument that popular culture is the culture of all people, regardless of class, ethnicity, or gender, and it can be interpreted in many ways because it is the people who derive meanings from its elements. The vignette "The Red Clowns", which portrays Esperanza's unpleasant carnival experience, is an example of such re-contextualization of cultural elements. As Fiske argued, carnivals were symbolically connected with the emancipation of people from moral constraints, conventions, and predetermined truths: "Its function was to liberate, to allow a creative playful freedom" (1989: 82). Moreover, according to Keith, carnivals and festivals "are not just an aesthetic and commercial space where physical and bodily plea- 
sures are enacted, represented, and marketed; it is an arena where social values and meaning are put on public display, negotiated, and contested" (2008: 120). Hence, some elements of popular culture, such as carnivals or festivals, can be viewed as distinct social spaces that provide resistance against hegemonic practices. Carnivals play a significant role in Latino culture as well, as they reflect a space of cultural negotiation, featuring elements from Latin American ancestral history that recall Indian, African, and European origins. As a result, many Latino/a immigrants in the United States celebrate carnivals not only as popular social forms but with deeper meaning that lies beneath the surface of mere popularity, linked to the struggle of ethnic identities in diaspora and resistance to neocolonial tendencies.

However, for Esperanza, the young protagonist, carnivals are a source of trauma rather than an act of liberation or enjoyment, as she becomes a victim of rape at one such event. The traumatic experience completely alters Esperanza's view of carnivals. For her, the carnival invokes neither joy nor pleasure, but becomes a daily reminder of her negative experience, further implying that, regardless of what popular culture imposes collectively, each person derives meanings individually. For example, tilt-a-whirl, a symbol of popular culture, becomes a cognitive landmark of rape for Esperanza. Unlike other people, she remembers the carnival as the day the sky fell, when carnival colors started to whirl in her head, and red clowns laughed as they walked by her wounded body (CISNEROS 1991: 100). The chapter "Red Clowns" also suggests that, though entertaining, popular culture is not only ignorant but sometimes even hostile towards people from minority groups, like Esperanza. As Fiske observed, commonly depicted victims or villains in popular culture, on TV shows or in books, are those who reflect the beliefs and characteristics of oppressed groups (1989: 135). Accordingly, Cisneros portrays the female character Esperanza as a victim in the novel. She is a girl and a member of a U.S. minority, and both of these characteristics make her more vulnerable to abuse in U.S. popular culture. Therefore, the entire chapter exemplifies how, through its obvious liberal bias, aspects of popular culture may acquire a negative connotation and meaning.

As previously noted, there were not too many elements in early popular culture at the time that explicitly applied to ethnic minorities. Despite this, some of them, especially second- or third-generation immigrants, readily accepted aspects of American popular culture. Esperanza, for example, is seduced by popular family images symbolically exhibited in the house on the hill, as given in the passage below:

"I want a house on a hill like the ones with the gardens where Papa works. We go on Sundays, Papa's day off. I used to go. I don't anymore. You don't like to go out with us, Papa says. Getting too old? Getting too stuck-up, says 
Nenny. I don't tell them I am ashamed - all of us staring out the window like the hungry. I am tired of looking what we can't have. When we win the lottery... Mama begins, and then I stop listening" (CISNEROS 1991: 86).

Esperanza's mother, on the other hand, hopes that the family will win the lottery, giving them the opportunity to leave the life of an immigrant behind. She seeks solace in one of the most common forms of entertainment available to her - the lottery. Since this form of entertainment is widely accessible to lower classes in popular culture, Esperanza's mother redefines the game as more than just a type of popular entertainment, but a solution to the family's existential crisis. Esperanza, who stops listening when her mother begins romanticizing about winning the lottery, is tired of unreasonable expectations. Hence, much like the meaning of the carnival, the lottery has various meanings in Esperanza's case. Unlike her mother, she does not have a romantic view of games of chance because she is pragmatic about the chances of winning. Hence, adding credence to the earlier point concerning the adaptability of meanings derived from popular elements, the lottery game is just another example of how an element of popular culture can have different meanings for different people.

While she does not believe in winning the lottery, Esperanza's narration is heavily influenced by the 1950s concept of the American dream contained in the image of a happy family, comprising both parents and two or three children, a stable income, nice home, and a car. Esperanza often invokes the motif of the American dream in the book, as she fantasizes about a nice house away from Mango Street. The oneiric house for Esperanza, like the lottery for her mother, is a way for her to separate herself from the barrio and step away from the life of an immigrant, impacted by stigma, social and gender subordination. Throughout the book, Esperanza longs to escape a life marked by cultural and social displacement, as well as identity confusion, seeking comfort in the American dream, a popular myth characterized by opportunity, self-reliance and Manifest destiny. The motif of the American dream is also invoked in the car metaphor, in the vignette, in which Esperanza's problematic cousin steals a brand-new Rolls Royce and invites Esperanza, her sisters, and friends for a ride. The automobile motif in the novel is significant given that car culture has been an important characteristic of American popular culture. As Edensor writes, "the variety of qualities associated with cars and the range of identities and practices associated with automobiles infest popular culture. Notions of desire and sexuality, mobility, status, family-related activity, independence, sports, adventure, freedom and rebellion play across films, advertisements and fiction" (2002: 123). The Rolls Royce in The House on Mango Street reflects, in particular, both value and luxury, and as such solely falls into the category of fantasy for many Latino immigrants, such as Esperanza's cousin, who 
is ultimately caught by the police and taken to jail. While debatable whether the U.S. ever provided its citizens with a fair opportunity for upward mobility, more importantly, the Rolls Royce episode was used by Cisneros to shatter the possibility of the popular American dream myth. Specifically, though some readers may hold universal meanings for cultural markers such as carnivals representing fun and entertainment, lotteries representing luck and opportunity, and luxury cars representing prestige and social status, their meanings are subverted and largely (re)appropriated by Cisneros.

While some aspects of popular culture provided what Harris called "the illusion of belonging" (2009: 289), ethnic minorities in the United States were largely underrepresented, and as a result, they simultaneously relied on elements from their original cultures for identification and representation. In Esperanza's case, there is a strong echo of both popular and Mexican culture, symbolically embodied in Cisneros's code-switching narrative technique. In the novel, Esperanza uses English slang - another peculiarity that has gained more popularity with the advancement of U.S. popular culture - and combines English with Spanish words, thus emphasizing her bilingualism and biculturalism. Other characters in the novel are also caught up in similar cultural and linguistic dialectic. Readers discover this when Esperanza reveals that her neighbors similarly try to imbue Latino values into their American realities. For example, in the vignette "No Speak English", Esperanza speaks about an elderly Mexican woman Mamacita who paints her home walls pink in the middle of Chicago to evoke the colorful appearance of houses in Mexico. Another vignette, "Elenita, Cards, Palm, Water," portrays Elenita - an elderly Chicana foretelling the future, preserving old folk tales and superstitions, and making traditional remedies. Although Elenita lives on U.S. territory and allows popular elements into her daily life, such as watching Bugs Bunny on a color TV, she still maintains the old ways of living preserving the elements of her original tradition and culture. Like other characters, she does this not only out of nostalgia and homesickness, but because American popular culture cannot fully encompass the bicultural experience. While Elenita lives in a country where she cannot avoid the influence of burgeoning popular culture, she obviously achieves a kind of compromise by incorporating aspects of both American and Latino culture into her life. Evidently, as in many novels of Chicana literature, characters in The House on Mango Street blend different cultural elements, their past and present, in search of the most appropriate meanings within the bicultural existence. In doing so, the characters in Cisneros's novel alter the meanings of cultural elements and produce "a counter-discourse that provokes the destabilization of the vision of the U.S. as a single 'imagined community' and of the representations that promote such vision" (HARRIS 2009: 284). 


\subsection{Female Stereotyping in U.S. Popular Culture and Chicana Position}

Given that patriarchal activity in the United States in the 1950s devoted much attention to restoring women to their previous roles, ${ }^{3}$ popular culture became a means of communicating patriarchal messages about female domestic roles, mostly through images of maternity, domesticity, female goodness, sensitiveness, and so on. These kinds of messages had an impact on all women in the United States, regardless of race or ethnicity. The only distinction between white and ethnic minority women was that the latter were subjected to additional racial and ethnic prejudice. As a result, the 1950s in America were a time when women of all races received various messages about their subordinate place in society. As mentioned earlier, these messages were delivered through various channels, most notably the media, and had a significant impact on the self-positioning and self-perception of those to whom the messages were directed. The novel The House on Mango Street thus reflects several female stereotypes prevalent in 1950s popular culture, one of which is a housewife stereotype. Namely, some female characters in the novel are either depicted as housewives or girls who, for different reasons, tend to become housewives. For example, Esperanza's friend Sally wishes to marry and become a housewife in order to escape her abusive father; she seeks protection in another male figure - husband, and fancies everything that constitutes the described family ideal. Esperanza, on the other hand, defies the popular stereotype by wishing for a house of her own. This differs from the patriarchal model in which the family house is typically owned by a man, usually the husband and father. Her desire to leave Mango Street implies a need to shift the female position and undermine current power relations - both between men and women, as well as between white Anglo society and ethnic minorities. Her younger sister Nenny, as Esperanza tells, exhibits a similar aжttitude:

"Nenny says she won't wait her whole life for a husband to come and get her [...] She wants things all her own, to pick and choose. Nenny has pretty eyes and it's easy to talk that way if you are pretty" (CISNEROS 1991: 88).

Though neither Nenny nor Esperanza wish to depend on their husbands posing as a protective masculine figure, the paragraph's final sentence reveals that Esperanza still adheres to certain prejudices reinforced by popular culture, as she believes that only beautiful women have the privilege of having a careless attitude about marrying. Evidently, the female beauty was another popular stereotype in the 1950s and early 1960s popular culture - until the Women's Movement began working against this and other deeply ingrained female stereotypes of the time. As shown in the book, Esperanza is seduced by the popular myth that beautiful women like Nenny are given more power and 3 Domestic roles occupied by women prior to WWII. 
options in life. Clearly, the beauty stereotype works in such a way that it seduces women into thinking that beauty confers power. As explained by Naomi Wolf, the beauty myth was so influential because once "women released themselves from the feminine mystique of domesticity, the beauty myth took over its lost ground, expanding as it wanted to carry on its work of social control", as well as because "the aspirational promise of women's magazines that women can do it all on their own was appealing to women who until recently were told they can do nothing on their own" (2002: 10, 29).

Furthermore, the beauty stereotype in the novel is related to another contentious issue - the sexual objectification of women. The 1950s were the times when popular culture did not propagate female beauty alone, but also presented women as sexual objects and compared them to various material goods. This was done mainly through the media, magazine advertisements, commodity commercials, and the like. Accordingly, some female characters in the novel are overly sexualized and reduced to the function of an object. This is apparent, for example, when a street bum makes a remark to Esperanza's friend Rachel: "Rachel, you are prettier than a yellow taxi cab" (CISNEROS 1991: 41). Obviously, the bum not only compares Rachel to a car but utterly dehumanizes her. Although Fiske notes that sexual implications and promotion of body or bodily pleasures in popular culture serves to challenge or oppose power blocks and defy traditional notions of socially acceptable behavior (1989: 53-54), the exaggerated promotion of sexual characteristics and female objectification in the novel serves to exert and maintain patriarchal control. Additionally, some common commodities listed in the novel, such as lipstick, high heels, or nylons, do not emphasize the attractiveness of the female characters like Rachel, Esperanza or Sally but elevate the appearance of young girls into the realm of travesty. By this, Cisneros parodies the beauty stereotype, as the young female characters do not look more attractive with lipstick, make-up, and nylons on. On the contrary, they appear rather ridiculous with looks that do not conform to their age:

"It's Rachel who learns to walk the best all strutted in those magic high heels. She teaches us to cross and uncross our legs, and to run like a double-Dutch rope, and how to walk down the corner so that shoes talk back to you with every step. Lucy, Rachel, me tee-tottering like so. Down to the corner where the men can't take their eyes off us. We must be Christmas" (CISNEROS 1991: 40).

Importantly, female characters in the novel are constrained not only by stereotypes in American popular culture but also by stereotypes embedded in their original culture, in which women were subjected to male domination and authority too. In the vignette "Rafaela Who Drinks Coconut and Papaya Juice on Tuesdays", Esperanza explains how her neighbor Rafaela spends 
most of her time locked in her home, waiting for her husband, who thinks she will flee because she is too beautiful (CISNEROS 1991: 79). For Rafaela, her good looks lead to a state of entrapment rather than empowerment. Apart from viewing Rafaela as a weak Latina suffering due to her husband's false notions, Cisneros here exposes the underlying male insecurity and undermines the prevalent machismo ${ }^{4}$ stereotype in Latino culture. In that regard, Rafaela's case is notable because it reveals that the Latino community also held some prejudiced views about female beauty, most likely emerging from masculine insecurity, which lends credence to the point that Latinas in the U.S. were constrained by both American and Latino cultural stereotypes, as neither culture provided space for the repositioning of women.

Alternatively, by the end of the novel Cisneros works to deconstruct female stereotypes by re-conceptualizing the notions of female beauty and sexuality. In the vignette "Beautiful and Cruel", Esperanza ultimately rejects the housewife stereotype embedded in both cultures, deciding to become just like that beautiful and cruel woman, the fermme fatal, she sees in the movies: "In the movies there is always one with red, red lips, who is beautiful and cruel. She is the one who drives the men crazy and laughs them all away. Her power is her own. She will not give it away" (CISNEROS 1991: 89). As Chakraborty observes, Esperanza aspires to become a strong and self-convinced woman "whose power is her own so that she can neither be appreciated nor fathomed by a man" (2013: 115). Moreover, in choosing to be "beautiful and cruel" at the same time, Esperanza juxtaposes beauty and cruelty, thus completely undermining the popular beauty stereotype. Considering that she deems herself ugly throughout the most part of the novel, at this point Esperanza openly rejects conventional concepts of femininity embedded in both cultures. In doing so, she disrupts the long-established connection between beauty and other patriarchally enforced feminine characteristics, eventually fracturing the culturally ingrained dialectics of beauty, tenderness, submissiveness and subordination.

\section{Conclusion}

The novel The House on Mango Street demonstrates how Latina/o ethnic minority characters fit into the context of 1950s popular culture in the United States, deriving cultural and social meanings from a wide range of popular elements. Despite insufficient cultural representation of ethnic minorities in early American popular culture, this paper illustrates how characters in the novel, especially the female ones, engage in American popular discourse. Despite the fact that America entered a period of growth in the 1950s, with major social changes to come in the following decade, popular culture remained op-

4 Machismo denotes manly characteristics attributed to Mexican men, but not limited to them, such as courage, power, cleverness, rationality, strength, etc. 
pressive towards women, who were restricted by the restoration of the housewife status, family, and female beauty standards in the 1950s. In fact, official policies that promoted the restoration of America's positive global image, family and gender politics, as well as many female stereotypes and standards such as female beauty, served to further confine women within the existent patriarchal gender roles. As the novel implies, these social constraints did not exempt ethnic minority women either, as Chicanas were unable to avoid the influence of popular culture and its references to the social role of women at the time. However, unlike white middle-class women, women of color, such as Chicanas in Cisneros's novel, lacked appropriate points of reference and positive representation in the American popular setting and, as depicted in the novel, these women were jointly constrained by ethnic and gender inequality, the latter of which originated in both their original culture and American popular culture.

\section{Works Cited}

CHAKRABORTY 2013: CHAKRABORTY, Suryendu. "Social and Imaginary Space in Sandra Cisneros's The House on Mango Street". Wizcraft Journal of Language and Literature, Vol. 2, Issue 1 (April 2013): p. 88-121.

CISNEROS 1991: CISNEROS, Sandra. The House on Mango Street. New York: Vintage Books, 1991.

EDENSOR 2001: EDENSOR, Tim. National Identity, Popular Culture and Everyday Life. Oxford and New York: Berg, 2001.

FISKE 1989: FISKE, John. Understanding Popular Culture. London and New York: Routledge, 1989.

HARRIS 2009: HARRIS, A. Leila. "The Deconstruction of Cultural Icons in the Fiction of Sandra Cisneros and Helena María Viramontes". In Gonçalves, Gláucia R. and Sandra R.G. Almedia et al. (Eds.), New Challenges in Language and Literature, Belo Horizonte: Faculdade de Letras da UFMG, 2009.

HOLT 2005: HOLT, Jennifer. "The Ideal woman”. Soundings. Spring 2005. URL: https://www.csustan.edu/sites/default/files/honors/documents/journals/ soundings/Holt.pdf > 4. 2. 2020.

MADSEN 2003: MADSEN, Deborah. Beyond the Borders: American Literature and Postcolonial Theory. London: Pluto Press, 2003.

MUJČINOVIĆ 2004: MUJČINOVIĆ, Fatima. Postmodern Cross-Culturalism and Politicization in U.S. Latina Literature. New York: Peter Lang Publishing, 2004. NURSE 2008: NURSE, Keith. "Geoculture and Popular Culture: Carnivals, Diasporas, and Hybridities in the Americas". In Smith, Keri E. I. and Patricia Levy. Hybrid Identities: Theoretical and Empirical Examinations. Leiden: Brill, 2008.

O'KEEFE 2014: O'KEEFE, Bridget (2014), "Happiness, Womanhood, and Sexualized Media: An Analysis of 1950s and 1960s Popular Culture". New Errands, Vol. 2, Issue 1 (October 2014): p. 56-63. DOI: https://doi.org/10.18113/ 
P8ne2159261

RUTHERFORD 1990: RUTHERFORD, Jonathan. Identity, Community, Culture, Difference, London: Lawrence and Wishart, 1990.

BAIN-SELBO 2010: BAIN-SELBO, Eric. "The Politics of the Romanticization of Popular Culture, or, Going Ga-Ga Over Pop Culture: A Critical Theory Assessment”. TopSCHOLAR. 2010. URL:https://digitalcommons.wku.edu/cgi/ viewcontent.cgi?article=1009\&context=phil_rel_fac_pub, 4. 12. 2020.

HALL 1998: HALL, Stuart "Notes on Deconstructing the Popular". In John Storey (ed.), Cultural Theory and Popular Culture: A Reader. 2nd Ed. New Jersey: Prentice Hall, 1998.

WILLIAMS 1983: WILLIAMS, Raymond. Keywords: A Vocabulary of Culture and Society. New York: Oxford University Press, 1983.

WOLF 2002: WOLF, Naomi. The Beauty Myth. New York: Harper Collins, 2002.

Mirna M. Ćurić

\section{PROMIŠLJANJA O POPULARNOJ KULTURI U ROMANU SANDRE SISNER- OS KUĆA U ULICI MANGO}

Rad istražuje elemente popularne kulture u romanu Sandre Sisneros Kuća u ulici Mango. Teorijski pristup koji je dat u prvom dijelu rada predstavlja najvažnije aspekte rane američke popularne kulture, dok se drugi dio bavi odnosom popularne kulture i etničkih manjina - Latinoamerikanki u romanu Sandre Sisneros. U radu se posebno naglašava višeznačnost koju popularna kultura ima za etničke manjine u SAD-u, kao i činjenica da, iako je prihvatila egalitarne ideale i generalno djelovala progresivno, ova kultura nije uspjela da integriše kulturološke i rodne perspektive Latinoamerikanki, što se potvrđuje i nedostatkom kulturne zastupljenosti i stereotipiziranjem ženskih likova u romanu.

Ključne riječi: popularna kultura, mediji, reprezentacija, etničke manjine, Čikana, rod, patrijarhat, Cisneros 